\title{
電子書籍フォーマットXMDFと作成環境
}

\section{XMDF E-Book Format And Its Authoring Tools}

\author{
花田恵太郎 ${ }^{1 *}$, 梅本あずさ ${ }^{1}$, 沢田裕司 ${ }^{1}$, 齋鹿尚史 ${ }^{1}$, \\ Keitaro HANADA ${ }^{1 *}$, Azusa UMEMOTO ${ }^{1}$, Yuji SAWADA ${ }^{1}$, Hisashi SAIGA ${ }^{1}$ \\ 1 シャープ株式会社 通信システム事業本部 ネットワークサービス事業推進センター \\ コンテンツシステム開発室
}

Content System Department, Network Service Business Center, Communication Systems Group, Sharp Corporation

†632-8567 奈良県天理市䊾本町2613番地の1

XMDFはシャープが開発した電子書籍フォーマットおよび技術である. 2001年にXMDFを用いた 電子書籍配信サービスを開始して以来, コンテンツのジャンル, 普及の両面で大きく拡大している. 2010年10月には, 表現力を大きく向上させたXMDF3.0 を発表し, これに基づいた新規電子書籍サ 一ビスを開始している. XMDFは単なるフォーマットではなく, 他フォーマットも含めて様々なコンテン ツをパッケージして配信するためのコンテンツコンテナへと進化している.

本稿ではXMDF3.0で採用した新機能を中心とする技術とコンテンツ作成環境について解説する. 多様化する電子書籍に対するニーズにこたえるため, 高い表現力をもったコンテンツを, 低いコスト で作成できるソリューションを提供している. 今後も, XMDF技術を応用して, 電子書籍産業の拡大に 貢献していくことを目指している.

This paper describes XMDF e-book data format and technologies, which have been developed by Sharp Corporation. The first e-book service based on XMDF started in 2001 and XMDF has expanded drastically in content genres and popularity ever since. It has also evolved to be a "content container" that packages contents of various formats not limited to XMDF for distribution.

The paper focuses on new features introduced with XMDF 3.0, its latest version. XMDF content production tools, which enable production of contents with a strong expression power at low costs, are also explained.

The authors are aiming to continue their contribution to the e-book industry with XMDF technologies, catering to diversifying needs in the market. 


\section{1 はじめに}

2010年は電子書籍元年という表現をよく 目にした年であり，電子書籍に関する新たな 取り組みが数多く発表された.シャープ株式 会社も2010年12月にクラウドメディア事業

「GALAPAGOS」の第一弾として，電子ブック ストアサービスと専用メディアタブレット 端末の販売を開始している. 当社の電子書籍 サービスの取り組みは最近始めたものでは なく2001年にまでさかのぼることが出来る.

本稿では, 当社が開発した電子書籍向けの 配信プラットフォームであるXMDFの最新状 況について紹介する.

\section{$2 \mathrm{XMDF}$ 技術とその進化}

\subsection{XMDFとは}

XMDF (ever-eXtending Mobile Document Format)は，2001年に当社の携帯端末「ザウ ルス」向け電子書籍サービスを支える電子書 籍フォーマットとして産声を上げた. 日本語 に訳せば，「進化し続ける携帯機器向け文書 フォーマット」である，その名のとおり，電 子コンテンツに対する要求と, 携帯端末の変 化に合わせて進化を続け, 現在では国内の文 字物 (小説) 系電子書籍のデファクトスタン ダードとなっている.XMDFに関してはいくつ かの文献 [1] [2] [3] [4]で解説されているの で詳細な説明は割愛するが, 簡単にまとめる と以下の特長を持つ.

・ コンテンツは, XMLの記述フォーマットで 作成し，それを独自バイナリの実行フォ 一マット, さらには暗号十改ざん検出付 き配付フォーマットに変換する

・日本語表現に必要となる, 縦書き, ルビ, 禁則, 外字などに対応し, 音声や動画な どのマルチメディア機能を有する
・文字物だけではなく, 辞書, コミック機 能を有する

・記述フォーマットは国際標準(IEC62448 Ed. 2 Annex B) として発行済み

\subsection{XMDFの進化}

図1はXMDFの進化を示す図である。XMDFは CPUパワーやメモリ量で大きな制約がある携 帯機器においても, 軽快な動作を提供するこ とを目標としている.フォーマットの策定だ けではなくコンテンツ作成環境, ビューアソ フトウェアをトータルソリューションとし て提供することにより,たとえ異なるメーカ の端末であっても, コンテンツ表示同一性と 軽快なパフォーマンスを実現してきた.ター ゲットとする端末がサービス開始当時の携 帯端末から携帯電話へと変わることにより, ユーザ層も大きく変化し, コンテンツも従来 の文字物に加えてコミックへの対応を行っ てきた。

近年，端末はスマートフォン，あるいは夕 ブレット端末へと大きく変化し, 通信環境の 充実, 表現・処理能力の向上を受けて, より ビジュアルな雑誌や, 速報性の高い新聞など 新しいカテゴリのコンテンツに対する要求 が高まってきている。

そこで我々は，そういった新聞・雑誌向け の表現力・機能も実現するXMDF3.0を開発し た.

\section{XMDF3.0}

一般に書籍などの印刷物は, 600〜1200dpi 程度の印刷解像度を持ち, 特に新聞, 杂隹誌に おいては物理的な紙面サイズもA1〜A4サイ ズと幅が広い.一方, 現在の表示デバイスは, 150 300dpi程度の解像度であり，当社のメ 


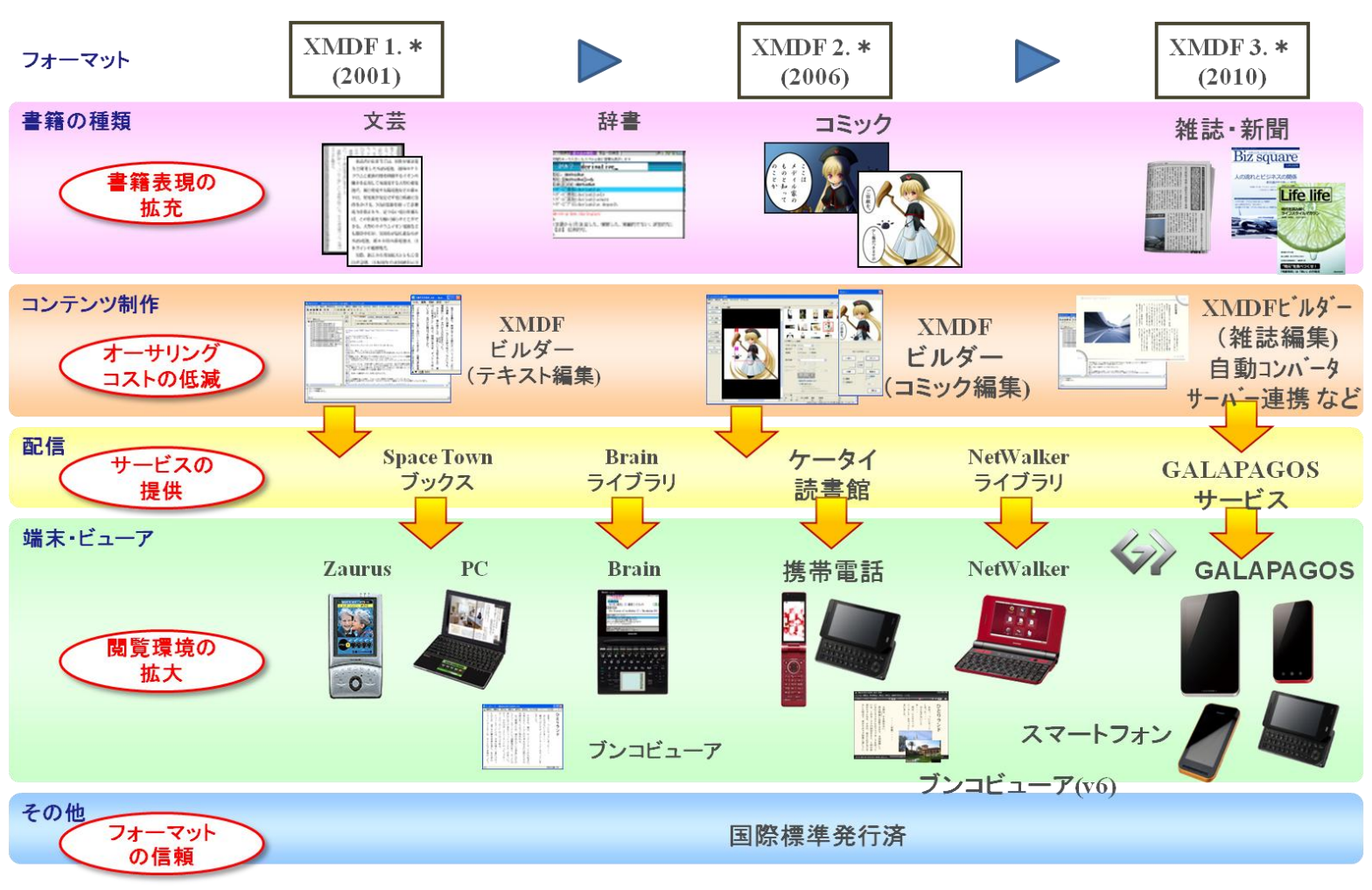

図 1 XMDF の進化

ディアタブレット端末であるGALAPAGOS端末 においても物理的な大きさは $5.5,7,10.8$ インチ, 画面の画素数は $1024 \times 600,1366 \times 800$ しかない，そのため，紙の1ページを，その まま表示デバイスで十分な閲覧性を保持し たまま表示することは困難である。

一方, 紙書籍, 特に新聞・雑誌の表現バリ エーションは多岐に渡る。紙書籍は, 読者へ のアピールと読み易さが究極まで追求され ているものである，出版社は, 紙の重さから 拘り, コンテンツに応じた紙の色やフォント 選び，紙面レイアウト，文章の校閲・校正， 見出しのインパクト性や読み易さを追求し た組み版の微修正, 大量の写真からべストの 1枚を選択するなど，編集者のセンスを最大 限に発揮した紙面作りが行われている. その 結果, 様々な紙面体裁が生み出され, 無限に 変化していると言える.
したがって，新聞・雑誌の電子書籍化にお いては, 紙に比べ圧倒的に少ない解像度・画 素数の表示デバイスで多様な表現を実現す る必要がある。さらにその上で，電子ならで はの機能をもつことも要求される.

また一方で, 従来の紙で出版されている新 聞, 雑誌のデータを用いて, 最低限のコスト で電子化を行いたいという要求も多い.

そこで我々は，XMDF3.0において以下に述 べる機能を採用し, 様々な要求に対してフレ キシブルに対応することとした。

\section{1 リフロー}

リフローは紙の1ページをそのまま表示す るのではなく, 端末の画面サイズやユーザが 指定する文字サイズに応じて, 動的にレイア ウトして表示する方式である.この方式では, 紙の 1 ページと電子書籍の 1 ページは対応し 
ないが, 文字の大きさを変化することにより レイアウトが崩れることがなくなる．また， 動的にレイアウトするので, 同じコンテンツ を表示デバイスの異なる様々な端末で利用 することが可能である.

リフローは, 挿絵画像が入る程度の小説系 では比較的容易だが, 様々なレイアウトを使 用する新聞・雑誌への適用は困難であった。 これらの多様な表現に対応するため, 従来の 縦書き,ルビ, 外字, 禁則などだけではなく, 下記の機能拡張を行っている.

・自動段組み

一つのテキスト領域内において，コンテン ツの設定に応じて，自動的に段組みを行い, その数も変化させる機能である. 1 行の最少 文字数，最大文字数を設定することにより， ビューアはこれら設定值に基づき, 段数を決 定し段組みを行う。もちろん, 縦書き, 横書 きのどちらでも自動段組みは有効である.ま た, 段組み間の買線設定や, 罫線を小片画像 の繰り返しで表現する「飾り罫線」も設定可 能である。

・画像の段端表示

段の境界で分離されると判断された画像 を，一方の段の端に表示する機能である。こ れは，上記自動段組を単純に実現すると，テ キスト内の画像が別の段 (上下, または左右 の段)に分離されるケースが出てくるため, これをを防ぐ為に導入した。

・文字，ルビ，字間，行間，余白設定

文字，字間，行間，余白のサイズ等の設定 をより詳細設定できるように強化した。また， ルビサイズも設定可能である.

また，上記の他，改行幅の設定，均等割り 付けの右寄せ, 左寄せ, 中央寄せ設定, 縦書 き時と横書き時で表示内容を切り替える設
定(例えば，縦書き時は「左図」，横書き時 は「下図」)，なども導入し，より細やかな 設定も可能とした.

このように，XMDF 3.0では，記事毎，端末 毎, 持ち方向毎, 行方向毎に, 自由に文字領 域，画像領域が設定でき，さらに文字領域の 中にも画像がインライン, 回り込みなど自由 に設定することを可能とした。これらを組み 合わせることにより多彩なバリエーション を実現している。

\section{2 レイアウトパターン}

新聞・雑誌は変化無限と言えども, 基本的 には画像とテキストで構成されている. XMDF3.0では, 対象表示デバイスに合わせて, これらの領域を自由に設定できるレイアウ トパターンを導入した.レイアウトパターン の画像領域は, ページをめくっても常に表示 され続ける固定領域としている.この目的は, テキストと画像の対応付けを実現する為で ある。

例えば，紙の新聞では，1つの記事の文章 と画像が常に見える。これは紙の場合,ペー ジという概念だけを念頭において, 関連する 文章と画像を配置すればそのままの形で読 者に提供できる。しかし端末の限られたスペ 一スでページをそのまま表示することは不 可能な上，リフローを行うことにより文章と 画像の位置関係が大きく変わることとなる．

「その写真を参照している文章にも関わら ず，写真が見えない」という問題を解決する 為に画像の固定領域を設けた.

また，固定領域を用いれば，新聞・雑誌の ロゴ，見出し，記事ヘッダーなどを常に表示 し続け，“そのコンテンツらしさ”を表現す ることも可能となる.

一つのレイアウトパターンには，自由に， 
いくつでも文字領域, 画像領域を設定するこ とを可能とした。また，複数の見せ方，端末 スペックに対応したレイアウトパターンを 持つことも可能にしている．例えば，下記の ようなバリエーションに対応するレイアウ トパターンを持つことにより，さまざまなユ 一ザの要求や端末に合わせて, 最適な表示を 実現することが可能となる.

・端末の縦持ち用・横持ち用

・縦書き用・横書き用

・画面解像度，画素数，アスペクト（縦横） 比

GALAPAGOS端末だけを例にとっても，5.5 型，7型と10.8型では，それぞれ画面の画素
数が異なる。これに，それぞれの縦持ち用・ 横持ち用，縦書き用・横書き用でレイアウト を変える場合は, 組み合せを格納する事にな る（図2）。

ビューアは, 現在の端末向けに最適化され たレイアウトパターンがあればそれを使用 し，なければ，最も近い端末向けレイアウト パターンを使用して, 指定されているアスペ クト比を保存した表示を行う。

リフローとレイアウトパターンを用いた 表示の切り替え例を図3に示す.

なお，画像は常に固定化されるわけではな い.ページをめくると表示されなくなる画像 は, 後述のテキスト領域内で設定可能である.

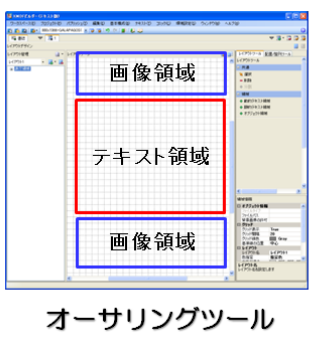

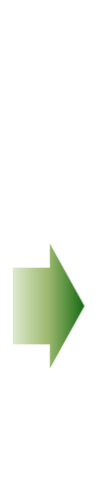

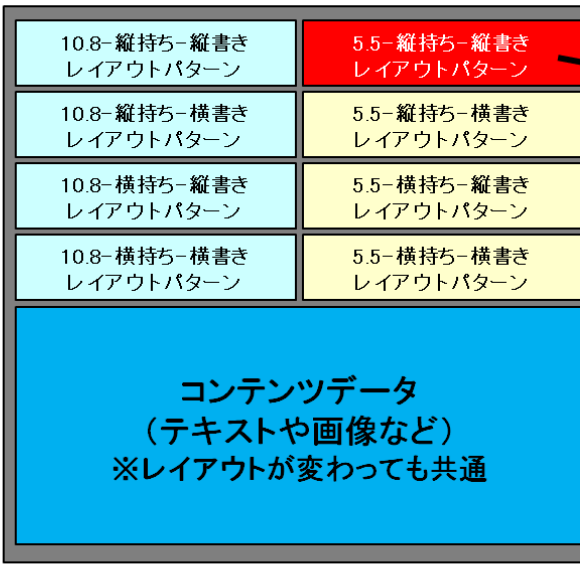

コンテンツファイル

※ーつにまとめられ、暗号化されている
ビューアは、最適なしイアウト パターンを選択して表示

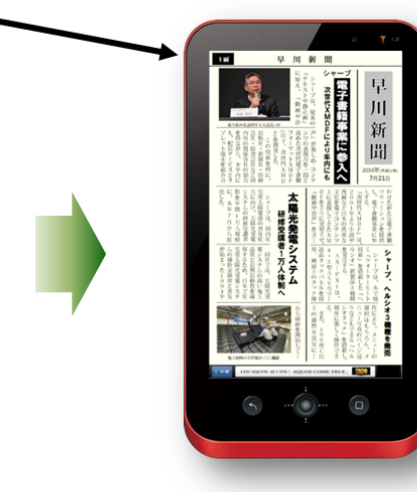

5.5型GALAPAGOS 縱持ち、縦書き時 ビューア表示例

図 2 レイアウトパターン
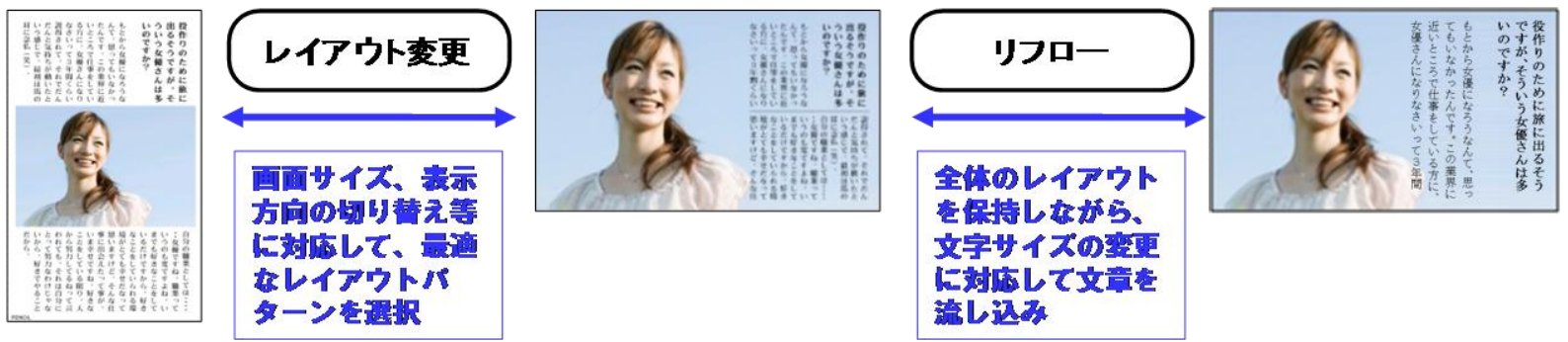

図 3 リフローとレイアウトパターンを用いた表示の切り替え例 


\section{3 イメージ型}

上述のようなさまざまな表現を実現する XMDF3.0であるが，一方で従来の紙で出版さ れている新聞, 雑誌のデータを用いて, 最低 限のコストで電子化を行いたいという要求 も高いため, 版面画像をべースとした形式も 採用している.これをイメージ型と呼ぶ.

イメージ型では, 全てのページを高解像度 の画像で構成している.レイアウト計算が不 要なため, 拡大/縮小表示や, ページをぱら ぱらめくるような使い方, ページのサムネイ ルを並べて表示し，読みたいページを拡大し， ドラッグして読むという読み方などを手軽 に行うことが可能となっている.

この形式では, 画面が縦方向に長いときに は片面のみ表示し, 横方向に長いときには見 開きで表示することも可能とした，また，右 綴じ／左綴じによる見開き左右の並びの制 御も可能とした.

\section{4 ハイブリッド型}

イメージ型は, 作成者にとっては最低限の コストでコンテンツを作成できるメリット があるが，読む側にとっては拡大・縮小と上 下左右のスクロールを繰り返し行う必要が あり, 特に複数段にわたるテキスト部分を読 むためには煩雑な操作を強いられることに なる。

そこで我々は, 上記イメージデータの各ペ ージに, その中に含まれるテキスト部分のみ をXMDF3.0で表現したものを付加し，イメー ジとテキストを簡単な操作で行き来しなが ら読む形式を採用した。これをハイブリッド 型と呼ぶ. ハイブリッド型においては，全体 のレイアウトや写真はイメージデータで閲 覧し, 細かい記事の内容を読むときはテキス
トモードに切り替えて, 読み進める.テキス トモードはXMDF3.0形式なので，リフローと レイアウトパターンを活用して最適な設定 でテキストを読むことが可能となる。

コンテンツの制作者は, 紙の書籍を作成す る過程で必要となるテキストデータと, 最終 でき上がりのイメージデータさえあれば八 イブリッド型のコンテンツを作成すること ができ, 非常に低コストで電子書籍ビジネス に参入することが可能となる.

\section{XMDFのコンテンツ作成環境}

電子書籍が普及するためには，その作成環 境の充実が鍵となる.コンテンツプロバイダ からみれば, 従来の紙による書籍の作成に加 えて, 電子書籍の作成作業が必要となり, 時 間的にもコスト的にも負担が大きくなる. 従 来の書籍作成環境をうまく活用しながら, 自 動化などの機能を備えることにより, 電子書 籍を簡単に作成する環境を提供しないと普 及はあり得ない。

電子書籍は, 各社が保持するデータを元に 制作することが多い，その制作作業は，デー 夕を整形・編集して電子書籍に仕上げる変換 作業と, 仕上がった電子書籍の内容が正しい か確認する査読作業との，2つの作業に大別 できる（図4）。

\subsection{XMDFビルダー}

変換作業においては, 次のような様々なデ 一タの編集が行われる.

- 日本語特有の圈点・ルビ・縦中横の付与

・インデントや揃えなどのレイアウトの調整 ・表示できない文字 (外字) の抽出と画像の作 成

・画像の挿入位置の指定や画質の調整 


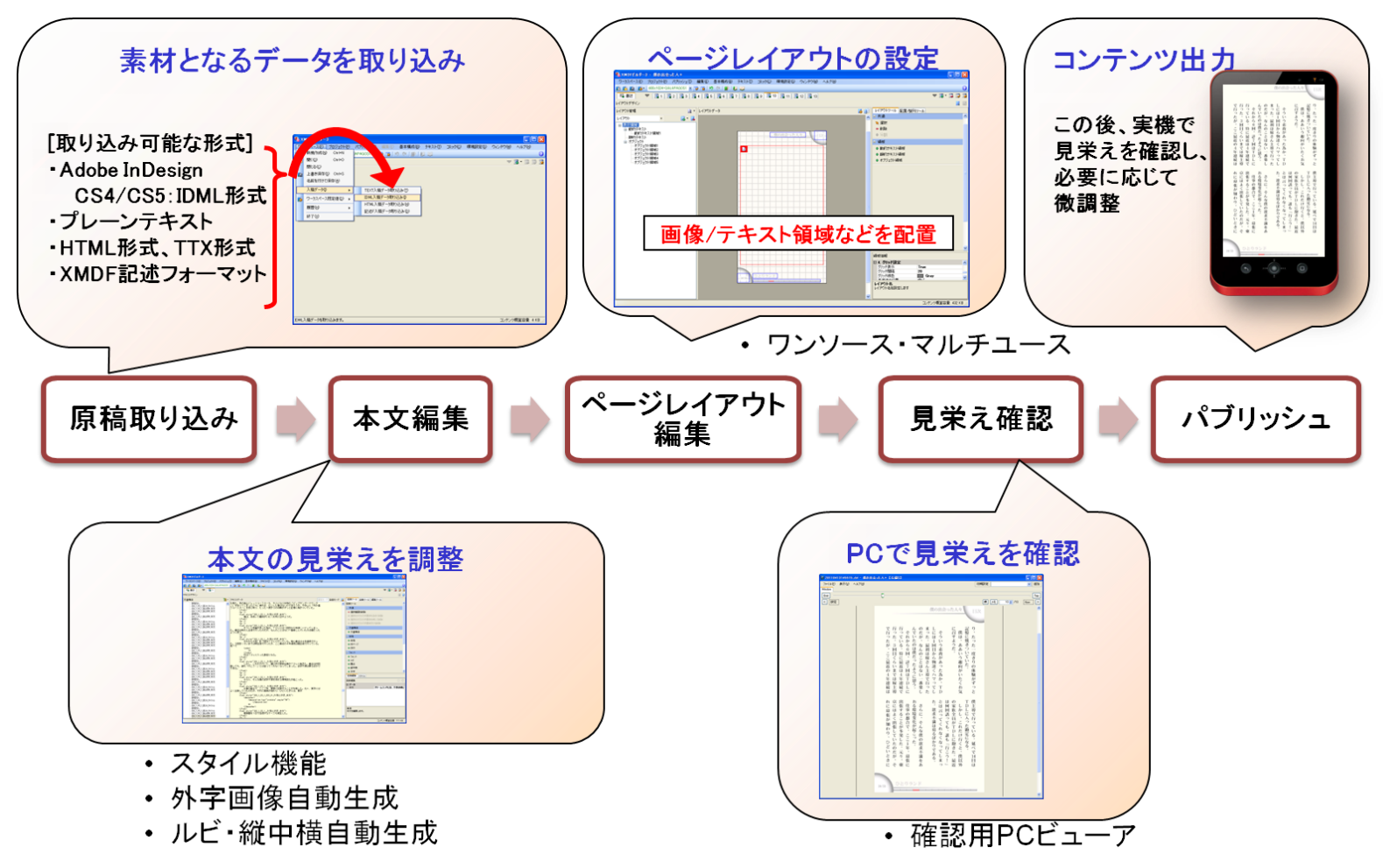

図 4 制作作業の流れ

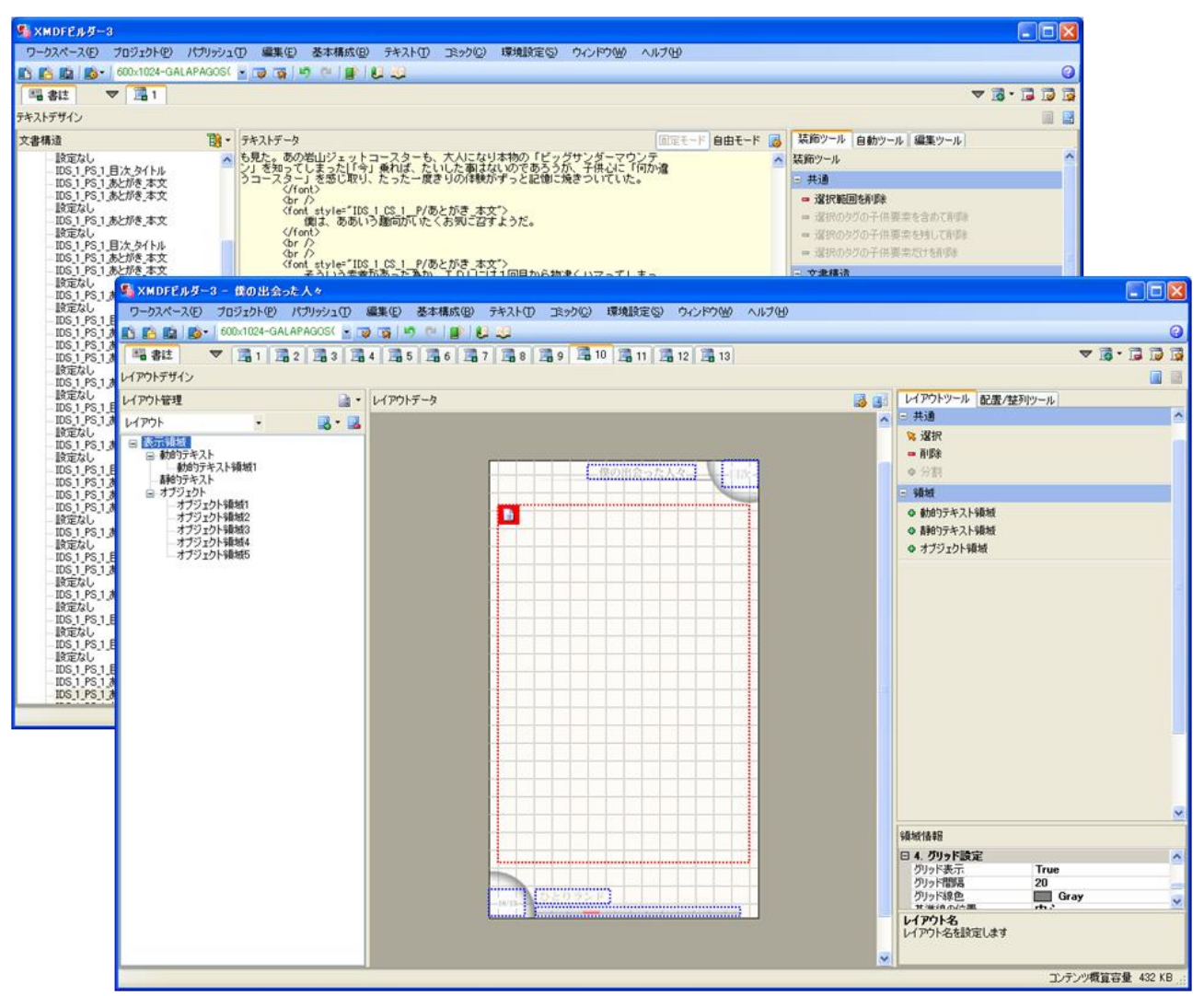

図 5 XMDF ビルダー 
・紙書籍では存在しないハイパーリンク, 動 画や音声の指定

上述の変換作業を行い, XMDF形式の電子書 籍を制作するためのツールとして，当社は XMDFビルダーを提供している（図5）。XMDF ビルダーでは, 次の機能を提供することで操 作量を削減して効率化を図っている.

\subsection{1 各種データの取り込み機能}

各社が保持するデータは, テキストファイ ルやHTMLファイル, 印刷用データのファイル など多種多様である.これらデータ形式に応 じて編集作業の内容が変わるため, データ形 式が複数の場合は, より多くの作業が発生す ることになる。

XMDFビルダーでは，これらのデータを取り 込む場合に, XMDF記述フォーマットと呼ばれ る共通のXMLファイルに自動でデータ変換す る.これにより, 多種多様なデータ形式は共 通のXMLファイルとして編集することが可能 となる。

\subsection{2 スタイル機能}

書籍では，見出しを本文より文字サイズを 大きくして文字色を変えるなどの表現が見 られる。このような表現は, 表示する端末に 応じてユーザに見やすいように調整するこ とが多く, 繰り返し同じ表現に編集し直す作 業が発生する.この課題をスタイルという機 能で解決している.

スタイルとは同じ表現をまとめて指定で きる機能である，例えば，「見出し」という スタイルは文字サイズを「大」, 文字色を「青」 とする指定をして, 各見出しの文字列の範囲 にスタイル「見出し」を指定する。後から文 字色を赤に変えたい場合, スタイル「見出し」
の中の文字色「青」を「赤」に変更するだけ で, 全ての見出しの文字列を赤へ変更するこ とを可能とした. 文字色や文字サイズの指定 の他, スタイルには改行や改ページも挿入で きるようにしている.このスタイルの機能の 導入により, 統一的なレイアウトの調整が可 能となっている.

\subsection{3 外字画像の自動生成機能}

現状，日本語を表示する端末の多くは Shift_JISで文字を扱っている. 従って, JIS 第 $1 \cdot 2$ 水準の範囲の文字のみが表現可能と なっており，JIS第 $3 \cdot 4$ 水準やUnicodeの範 囲の文字は表現することができない端末も 多い、書籍では，異体字などの表現も多いた め, 端末で表現できない文字は外字として扱 い, XMDF形式では画像として埋め込んでいる. 制作者は，どの文字が端末で表示可能かを判 断する必要があり, 表示できない文字であれ ば外字画像を作成する作業が発生する。

XMDFビルダーでは, 端末で表示できる文字 かどうかを判断し, 表示できない文字につい ては，予め指定したフォントを利用して画像 を生成し, 表示不可能な文字を画像で置き換 える処理を自動で行う機能を搭載している.

\subsection{4 ルビ, 縦中横の自動生成機能}

日本語特有の表現であるルビや縦中横は, 単純なテキストファイルではデータを指定 できないため, XMDF記述フォーマットのXML ファイルで大量に指定していく必要がある。

そこで，ルビを指定する機能として，ルビ 文字とルビを指定する親文字との対応テー ブルを準備し, 親文字に対応するテキストを 検出して自動でルビを付与することとした. また, 縦中横を指定する機能として, 英数字 や記号など指定された文字とその文字が連 
続する数を指定することで, 自動で縦中横を 付与することとした．

XMDFビルダーでは，このような自動生成機 能を導入することにより，作業の軽減を行っ ている.

\section{1 .5 ワンソースマルチュース機能}

電子書籍をより見やすいレイアウトで閲 覧できるようにするためには, 端末の画面サ イズに応じてコンテンツを制作し分ける必 要がある.しかしながら, 端末ごとに電子書 籍を一から制作し直していては作業が非常 に多くなってしまう。

XMDFビルダーでは, 一度編集した電子書籍 のデータを再利用し, 端末の画面サイズに応 じて, 領域や画像の大きさを自動で拡大縮小 する機能を導入している.これをワンソース マルチユース機能と呼んでいる.

この機能により, 一度の編集作業で, 複数 の端末, 複数の画面サイズに適した電子書籍 を，同時に制作することが可能となる。（図 5)

\subsection{Hybridコンバータ}

Hybrid コンバータは，イメージ型とハイ ブリッド型の電子書籍を制作するためのソ フトウェアである。

紙書籍の版面を表現するPDFファイルとそ れに対応するテキストデータを準備し, 順番 を指定するだけで電子書籍へ変換が可能で ある。

予め設定したテキストデータの整形規則 を用いて自動変換する機能により, 同じレイ アウトの電子書籍を大量に生成することが 可能となっている.

\section{3 確認用PCビューア}

査読作業において, 制作した電子書籍の表 示を確認するには, 実際に閲覧する端末で確 認するのが最適である。しかしながら，端末 への電子書籍の受け渡しの手間や, 確認した 内容を電子書籍と対応づけて残せないなど の課題がある.

そこで, $\mathrm{PC}$ 上で電子書籍を閲覧することに より査読作業を可能とする, 確認用PCビュー アを提供している．確認用 $\mathrm{PC}$ ごューアでは， 以下の機能で查読作業の効率化を図ってい る.

\subsection{1 端末プロファイル切り替え機能}

査読する端末の環境に合わせて表示する 機能である. 画面サイズやフォント名など端 末の環境を予妋定しておき, 設定した環境 を選択するだけで表示が変更され, 複数の端 末環境での査読作業を同時にできるように している.

\subsection{2 メモ機能}

查読作業を行いながら確認した内容をメ モすることができる機能である.このメモは, 製作者と查読者との間で情報伝達を行うた めに利用するものである.メモした内容は一 覧表示から選択することにより, 該当箇所へ 表示を移動させることができる.

\section{5 外部データの活用}

XMDF以外にも，ドットブック形式[5]や HTML形式など, 様々なコンテンツ記述フォー マットが存在し，また，それらのフォーマッ トで作成されたコンテンツも多数存在する. 今後は動画や音声等, 様々なメディアを含む 書籍の流通も増えてくることが期待されて いる．当社は，XMDF以外のフォーマットを， 


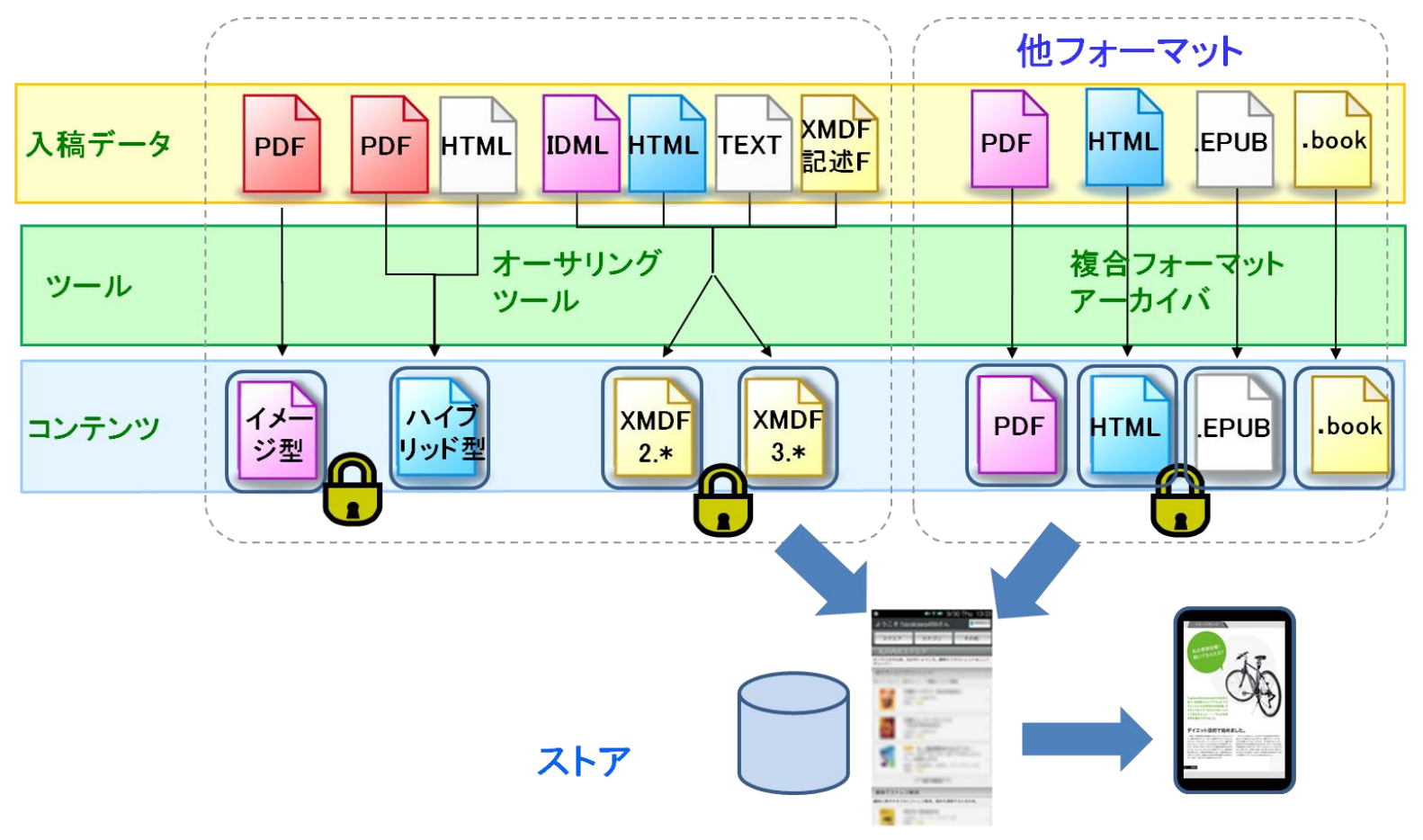

図 6 コンテンツコンテナの概念

競合相手（排除対象）ではなく，貴重なコン テンツ資産であると考えている。ゆえに，そ れらコンテンツ資産を活用すべく, XMDFを単 なるフォーマットではなく, 様々なコンテン ツをパッケージ化して配信することが可能 なコンテンツコンテナとして進化させてい る（図6）。

XMDFがコンテンツコンテナとして機能す るよう, 複合フォーマットアーカイバを導入 した. 複合フォーマットアーカイバは, XMDF 以外のフォーマットも一緒にパッケージす ることができるアプリケーションである. 複 数の電子書籍の順番を指定するだけで, 一つ の電子書籍に生成し直すことを可能として いる.

このアプリケーションの導入により, 他フ オーマットも配信することが可能となるほ か, 1 つの電子書籍を複数人で分担し効率的 に制作することも可能となった.

\section{6 むすび}

2011 年も引き続き電子書籍事業への参 入が相次いでおり，一層の成長が期待され ているが，一方で電子コンテンツを作成す るための時間的・金銭的コストが課題とな ってきている. 出版業界としても全面的に 紙から電子へのシフトというのは考えにく く, コンテンツ作成に関して，紙と電子の 二重投資が必要な状況である.

当社では, 本稿で紹介した XMDF ビルダー を, 電子書籍作成目的利用のために無償で 提供している.XMDF ビルダーのダウンロー ドなどに関してはホームページ $[6]$ を参照 されたい.ビルダーを利用することにより， 電子書籍作成のコストを少しでも下げるこ とができると自負しているので，一冊でも 多くの電子書籍を制作していただければ幸 甚である.

HTML5 や EPUB3. 0 など，新しい電子メデ イアの創出に主眼を置いたフォーマットも 使われはじめているが，我々はこのような 新しいフォーマットも活用しながら, 新し い表現形式の創出とコンテンツ作成コスト 
の低減により, 電子書籍産業の発展に貢献

していきたい.

\section{参考文献}

[1] 北村; 岩崎; 田中:「電子出版とXMDF技術」, シャープ技報，第84号，pp. 13-17， 2002.

[2] 田中：「電子出版文書フォーマット技術 動向調査報告書2010-2011」，インプレスR\&D, 5. 8, 2002.

[3] 中村：「国内電子ブック状況とXMDFのご紹 介」，「デジタル・ネットワーク社会におけ る出版物利用活用の推進に関する懇談会」資 料技， 2-2，2010.

[4]花田:「電子書籍に対するシャープの取り 組み」，ARIB機関誌，No. 73， 2011.

[5]株式会社ボイジャー:ドットブックの特 徵,

http://www. voyager. co. jp/dotbook/dotboo k. html

[6]シャープ株式会社:XMDF情報スクエア, http://www. xmdf. jp/ 